\title{
Adipose-derived stem cells in radiotherapy injury: a new frontier
}

\author{
Lipi Shukla ${ }^{1,2,3}$, Wayne A. Morrison ${ }^{1,2,3,4}$ and Ramin Shayan ${ }^{1,2,3,4 *}$ \\ ${ }^{1}$ Regenerative Surgery Group, O'Brien Institute, Fitzroy, VIC, Australia \\ ${ }^{2}$ Department of Plastic Surgery, St. Vincent's Hospital, Fitzroy, VIC, Australia \\ ${ }^{3}$ Regenerative Surgery Group, Australian Catholic University and O'Brien Institute Tissue Engineering Centre (AORTEC), Fitzroy, VIC, Australia \\ ${ }^{4}$ Department of Surgery, University of Melbourne, Melbourne, VIC, Australia
}

Edited by:

Swee T. Tan, Gillies McIndoe Research Institute, New Zealand

\section{Reviewed by:}

Jan A. Plock, University of Zurich,

Switzerland

Mario G. Solari, University of

Pittsburgh Medical Center, USA

\section{${ }^{*}$ Correspondence}

Ramin Shayan, O'Brien Institute, St. Vincent's Hospital, 42 Fitzroy Street, Fitzroy, Melbourne, VIC 3065,

Australia

e-mail: ramin.shayan@icloud.com
Radiotherapy is increasingly used to treat numerous human malignancies. In addition to the beneficial anti-cancer effects, there are a series of undesirable effects on normal host tissues surrounding the target tumor. While the early effects of radiotherapy (desquamation, erythema, and hair loss) typically resolve, the chronic effects persist as unpredictable and often troublesome sequelae of cancer treatment, long after oncological treatment has been completed. Plastic surgeons are often called upon to treat the problems subsequently arising in irradiated tissues, such as recurrent infection, impaired healing, fibrosis, contracture, and/or lymphedema. Recently, it was anecdotally noted - then validated in more robust animal and human studies - that fat grafting can ameliorate some of these chronic tissue effects. Despite the widespread usage of fat grafting, the mechanism of its action remains poorly understood. This review provides an overview of the current understanding of: (i) mechanisms of chronic radiation injury and its clinical manifestations; (ii) biological properties of fat grafts and their key constituent, adipose-derived stem cells (ADSCs); and (iii) the role of ADSCs in radiotherapy-induced soft-tissue injury.

Keywords: radiotherapy, adipose-derived stem cells, soft-tissue injury, autologous fat grafting, cancer, radiation, reconstruction

\section{MECHANISMS OF RADIOTHERAPY-INDUCED SOFT-TISSUE INJURY}

Over $50 \%$ of patients diagnosed with cancer (excluding nonmelanoma skin cancer) $(1,2)$ require Radiotherapy (RTX) for curative or palliative treatment (3-8). While RTX is classified as a "non-invasive" treatment modality, dose-delivery is limited by the capacity of surrounding normal tissues to tolerate radiation exposure (Figure 1). The acute/early side-effects (within 10-14 days) are most obvious in rapidly proliferating cells such as epithelial surfaces (epidermis and intestinal or respiratory mucosa) and bone marrow; and include desquamation, swelling, erythema, and pain $(2,4,9)$. These sequelae are followed by more unpredictable and progressively worsening late-onset chronic sideeffects (months/years after treatment) (10-15). Recent advances in public awareness, early detection, and adjuvant cancer therapies have led to significant improvements in cancer survival rates $(30 \%$ in recent decades) $(2,5,16,17)$. Consequently, more patients are living longer with a wider range of chronic RTX-related morbidities that impair their quality of life and increases their burden of disease (18); as well as leading to potentially life-threatening complications. Furthermore, in the case of cancer recurrence following RTX, treatment options become higher-risk and reconstructive surgical options more limited (19).

While acute manifestations of RTX are due to loss of functional cells through either apoptosis or cell death $(20,21)$, late RTX effects are less likely to arise due to these mechanisms (22). Instead, the initial sub-lethal indirect tissue damage results in an evolving disruption of key cellular repair mechanisms (23). Stewart et al. suggested that altered molecular signaling and formation of reactive oxygen species (ROS) cause single-stranded DNA breaks that repair incompletely, activating premature senescence, or accelerated differentiation pathways (21). According to Haubner et al. and others, these changes result in delayed RTX side-effects by further eliciting persistent localized cellular dysfunction, well after the early tissue reactions have subsided $(6,9,10,21,24-31)$. Stem cells within the injured area further recruit myofibroblast-like cells, which in turn contribute to chronic fibrosis $(32,33)$.

Meanwhile, Stone et al. hypothesized that in addition to losing reproductive capacity altogether, irradiated cells harbor sub-lethal injuries that perpetuate cell dysfunction through ongoing transcription of damaged DNA $(9,34,35)$. Therefore, the pathogenesis of RTX-injury is now considered a continuum of events that propagates damage to surrounding normal tissues, rather than a simple acute injury that creates an area of scarring $(21,36)$. Emerging work further suggests that an organized active biological release of inflammatory chemokines and cytokines may also establish a chronic inflammatory state in irradiated tissues $(1-8,10,21,24)$. Additionally, irradiated tissues also fail to regenerate normally when subsequently injured i.e., RTX-injury is a disease in and of itself.

In terms of the specific molecular signals implicated in the pathogenesis of RTX-injury, up-regulation of the TGF $\beta$ signaling is a mechanism common to numerous conditions of pathological fibrosis $(2-4,9)$, including fibrosis following cancer treatments such as radiotherapy or chemotherapy $(5,7,10-13)$. Brush et al. suggest that the impairment of normal healing results in 


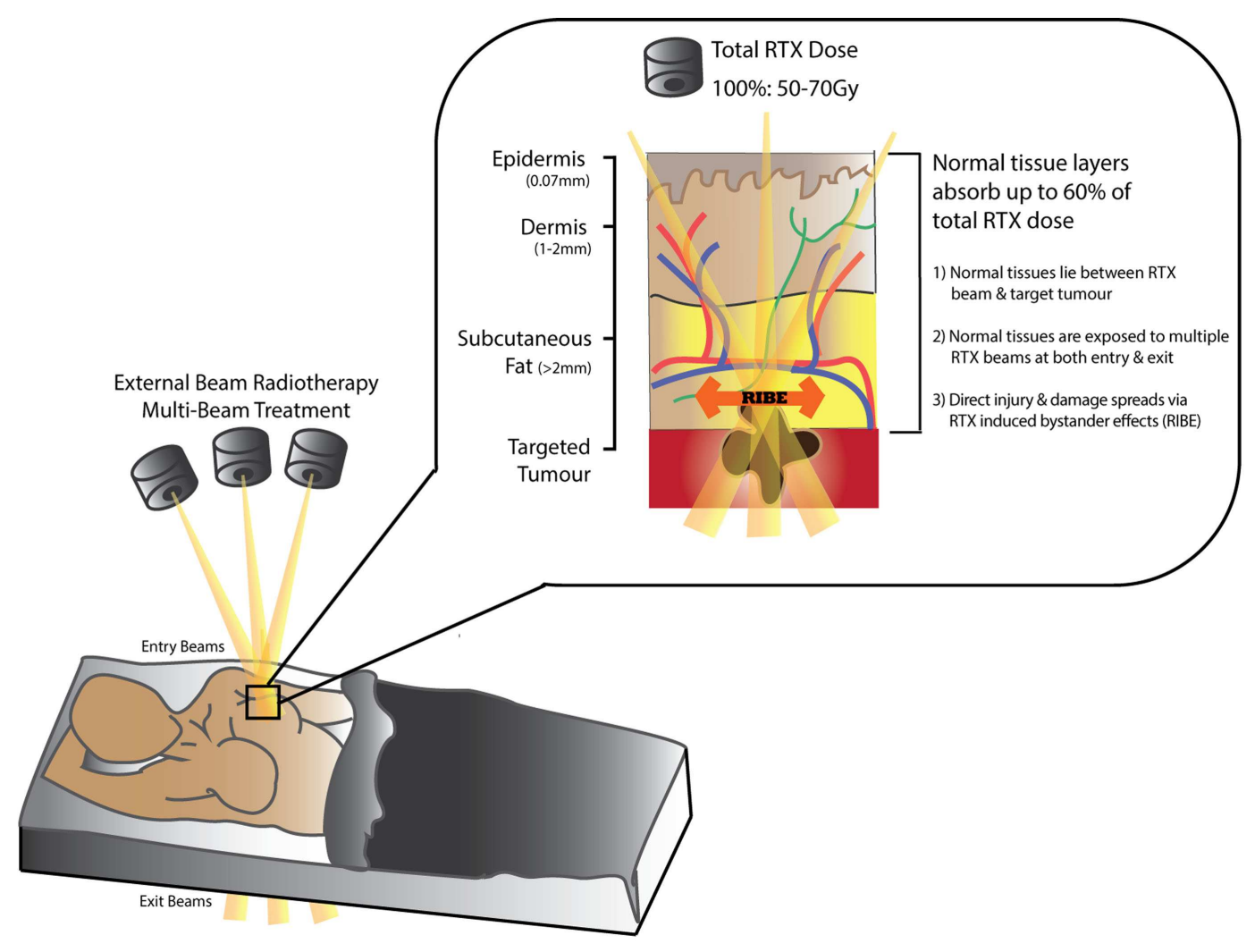

FIGURE 1 | Schematic diagram demonstrating tissue absorption of external beam radiation administered in radiotherapy (RTX). The RTX beam interacts with living tissues resulting in electron excitation, release of energy, and damage to both tumor and normal tissue cells. Normal tissues can absorb up to $60 \%$ of the total RTX dose targeting the tumor. Measurements in $(\mathrm{mm})$ represent distance from skin surface.

compensatory hyper-activation of fibrotic pathways, in order to maintain tissue structure and integrity $(10,14,15)$. Work by Lee et al. demonstrated persistent TGF $\beta$ - 1 over-expression in irradiated tissues, even after 6 months $(2,14,16)$; alterations that may in turn influence the function of fibroblasts, endothelial cells, lymphocytes, macrophages, and platelets $(5,7,17)$. Tibbs et al. characterized the key cellular functions of TGF $\beta$, including initiation of tissue matrix production and stimulation of chemotactic migration of fibroblasts and monocytes $(12,18)$. In contrast, Randall et al. showed oscillating TGF $\beta$-1 expression - decreased in the first $3 \mathrm{~h}$ after RTX (normalizing by 2-7 days), then steadily increasing to up to $200 \%$ above normal levels more chronically (16, 19). Grose and Werner verified a role for TGF $\beta$ in RTX-induced fibrosis and investigated the modulation of downstream mediators such as Smad-3 $(17,20,21)$. They demonstrated accelerated reepithelialization and decreased inflammation in Smad- $3^{-1-}$ mice compared with control animals $(17,22)$. Despite this evidence, however, attributing specific cellular effects of RTX-induced fibrosis to such a broad regulator of fibrosis as TGF $\beta$ has its limitations. The TGF $\beta$ super-family has multiple effects on numerous tissues and therefore therapeutic approaches that target this molecule may have insufficient specificity to ameliorate RTX damage, without jeopardizing other biological processes to which fibrosis is integral.
The focus of clinical and scientific research investigating RTX has, therefore, begun to shift from the initial insult to the modulation of subsequent processes such as inflammation $(37,38)$ and repair/remodeling $(6,9,20-26)$, in order to reduce harmful sequelae of RTX-induced soft-tissue injury. Impaired regeneration of irradiated tissues may also arise through a lack of available stem cells to mediate the repair process (see below). Finally, microvascular damage and lymphedema are also emerging as key features of chronic radiation injury; and it is in the light of shifting paradigms in our understanding of the field that we present a review of experimental and clinical adipose-derived stem cell (ADSC)based approaches to RTX-induced soft-tissue injury to date. NB: Although, RTX dosage and delivery regimes are related to potential morbidity, they are beyond the scope of this review.

\section{BIOLOGICAL PROPERTIES OF FAT GRAFT AND ADSCS}

Adipose tissue is heterogeneously distributed around the body and variable between individuals. Fat is mainly composed of lobules of mature adipocytes, and has mechanical and esthetic functions as well as roles in metabolism - a highly specialized type of connective tissue responsible for insulation, protection, and energy regulation $(21,25,27)$. The bulk of the non-adipocyte component, the cells within the stromal vascular fraction (SVF) are from mesodermal or mesenchymal origin and include pre-adipocytes, fibroblasts, 
endothelial cells, vascular smooth muscle cells, immune cells, and ADSCs (Figure 2) (27-31, 39-42).

Plastic surgeons use fat in vascularized tissue flaps, nonvascularized composite grafts, or stand-alone grafts in fat transfer $(28,30,32)$. The relative abundance of adipose tissue in most patients and ease of obtaining fat by lipoaspiration/liposuction with minimal donor morbidity has expanded the range of clinical indications for fat grafting; such as correcting cosmetic or contour defects, contractures, and lymphedema (30, 33, 44, 45).

Initially in clinical observation $(9,30,36)$, then in animal models $(15,34,46)$; fat grafting was reported to improve the characteristics of overlying skin and soft-tissue in RTX-injury $(6,30$, $35,46,47)$. Subsequent clinical analysis verified softening of wrinkles or fibrotic tissue and resolution of pigment changes $(21,36$, $39,46,48)$. Clinical reports suggested that fat grafting may also reduce peri-prosthetic capsule contracture, vocal cord damage, and chronic ulceration; and that it may rejuvenate aging skin $(5,27$, $28,36,39,41,46-52)$. These clinical benefits were attributed to the regenerative properties of undifferentiated multi-potent ADSCs within the SVF of lipoaspirate $(36,53)$. ADSCs are thought to play a supportive role in adipogenesis and angiogenesis, while also modulating inflammation and immunity $(30,54-56)$. Therefore, a role for ADSCs/fat graft ameliorating RTX-injury would be of interest to those working in tissue engineering, regenerative medicine, and clinical plastic surgery.
However, despite promising clinical potential, a detailed understanding of the putative molecular mechanisms for ADSCmediated reversal of RTX-injury remains elusive $(36,44,57)$. Additionally, concerns have been raised that fat grafting following cancer treatment may enhance tumorigenesis in a former cancer bed (58-60). If fat grafting is to become a useful and validated clinical tool, these issues must be addressed. A thorough understanding of the molecular interactions and the functional and sub-cellular alterations caused by RTX-injury to ADSCs themselves is also needed. Without such insights, guidelines pertaining to the safety of fat grafting in these contexts cannot be developed $(43,60,61)$.

\section{ENHANCING FAT GRAFT TAKE USING ADSCS}

Due to the clinical origins of the field, the majority of mechanistic information regarding ADSC-mediated cellular effects has been derived from research investigating the enhancement of fat grafts. Therefore, in understanding what pathways may become activated in ADSC-mediated reversal of RTX soft-tissue injury, it is critical to first review this more well-established body of data.

A tissue graft is defined as autologous tissue transferred to a distant site, without its original blood supply. A fat graft therefore, must acquire a blood supply and nutrients from the tissue bed into which it is introduced, with early re-vascularization to prevent graft necrosis that leads to volume depletion $(50,62,63)$.

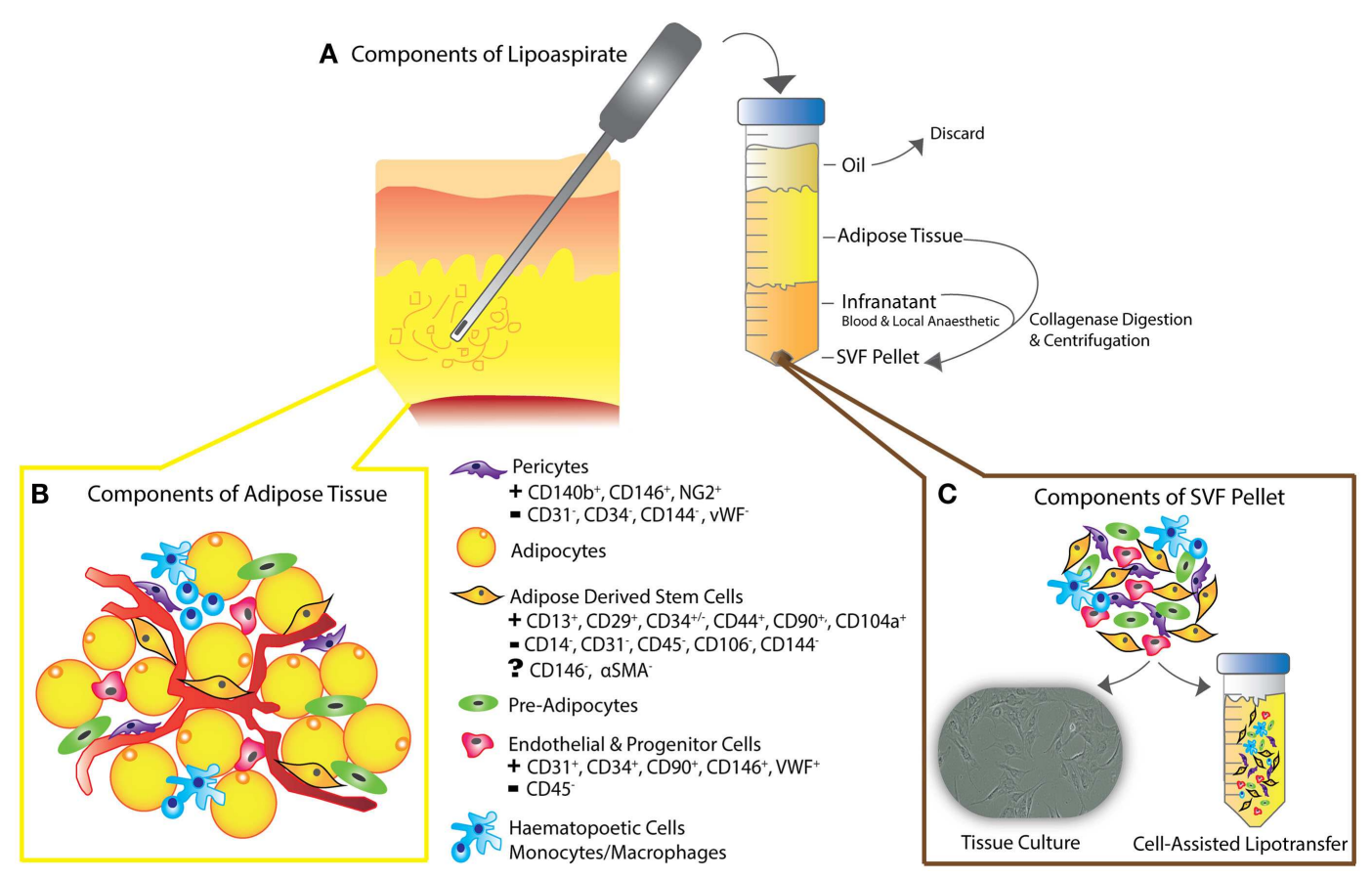

FIGURE 2 | (A) Schematic diagram depicting liposuction procedure - lipoaspiration of subcutaneous fat is performed, as previously described (30), followed by separation into layers of oil (discarded), aspirated adipose tissue, and infranatant (composed of blood, plasma, and local anesthetic). (B) The components of adipose tissue and the key constituents of the SVF pellet are all present in en-bloc in vivo adipose tissue as shown. Following collagenase digestion, incubation in control medium and centrifugation, the residual pellet is the so-called stromal vascular fraction (SVF). (C) SVF can be plated for tissue culture or added to unprocessed lipoaspirate as in the process of "cell-assisted lipotransfer" (43). The key surface markers of ADSCs, pericytes, endothelial, and progenitor cells are shown, demonstrating the unique surface antigen profile of each cell type that allows their differentiation from ADSCs (smooth muscle cells and fibroblasts not shown). 
Unfortunately, fat grafts may resorb up to $70-100 \%$ of the initial injected tissue volume $(30,64)$; a result attributed to poor graft neo-vascularization, apoptosis, and/or chronic fat necrosis (3943, 60, 63-65). While the many technical modifications to enhance fat graft take are beyond the scope of this review, ADSCs have emerged as a key focus of graft enhancement, and more recently as a critical component in reversing soft-tissue injury (66). ADSCs, first isolated by Zuk et al. over a decade ago $(28,67)$, were postulated by Eto et al. to be more robust than mature adipocytes in resisting mechanical trauma during fat transfer $(30,42,44$, $68)$, and to have lower metabolic demands $(27,28,39,48,49$, 62, 69-72). Others demonstrated improved graft survival through increased angiogenesis, incorporating either imported endothelial progenitors or ADSCs into blood vessels $(52,53,72)$. In contrast, Butala et al. suggested that introduced ADSCs may recruit further stem cells, particularly from bone marrow $(30,53,55,72)$. To enhance the relative ADSC abundance within fat grafts (44, 58, 72, 73), Yoshimura et al. proposed "cell-assisted lipotransfer enrichment" (Figure 2), by supplementing lipoaspirate with additional SVF $(23,43,60,62,64,74,75)$. The SVF [comprised $10 \% \operatorname{ADSCs}(45,46,65,67)]$, is obtained from a component of lipoaspirate, surplus to the volume anticipated to be required to fill a known defect (30). This surplus lipoaspirate is separated into components by centrifugation (Figure 2). Following collagenase digestion, further spinning produces a pellet, referred to as SVF. Finally, the SVF is re-introduced to the remaining lipoaspirate, in preparation for injecting the ADSC-enriched fat graft (28, 39, 42, 62, 68, 76-78). Later, Piccinno et al. explored graft enrichment using in vitro purified and expanded ADSC populations $(69,79)$, while $\mathrm{Lu}$ et al. and Shoshani et al. performed co-injection of pro-angiogenic factors IL-8 and VEGF-A (70, 71, 73). These studies collectively suggested that such enrichment may further increase graft viability, neo-vascularization, and volume retention, while reducing necrosis/apoptosis rates $(69,71,80)$. Building on this work, Kolle et al. conducted a randomized control trial to assess lipoaspirate-enrichment with ADSCs concentrations up to 2000 times above physiological levels (72, 81). ADSCenriched groups demonstrated higher volumes of graft retention on MRI at Day $121(30,72)$, and were associated with reduced apoptosis $(72,73)$. Overall, these findings further suggested that addition of ADSCs may improve graft take by enhancing adipogenesis, supporting angiogenesis and reducing cellular apoptosis $(53,54,72,82)$.

\section{ADSC CHARACTERISTICS AND IMMUNO-PROFILE}

Adult stem cells are uniquely able to differentiate into more specialized cell types, replenishing damaged cells to maintain tissue integrity and cellular homeostasis during growth or wound healing $(73,81)$. Such properties make mesenchymal stem cells (MSCs) prime candidates for use in tissue regeneration (23, 60, 74, 83-86). The clinical use of autologous MSCs for tissue regeneration confers several advantages - chiefly, the ability to avoid host-immune responses. The benefits of ADSCs, are that the yield of stem cells from adipose tissue exceeds that from bone marrow by about 500fold (75) $\left[5 \times 10^{5}\right.$ ADSCs may be isolated from 400 to $600 \mathrm{mg}$ of adipose tissue $(32,65)]$, along with superior ease of harvest and minimal donor site morbidity.
Similar to bone marrow derived stem cells (BMSCs), ADSCs are capable of differentiating into a diverse variety of mature tissues $(32,42,83)$ - skin, fat, cartilage, bone, muscle, endothelial, and neurogenic cells when cultured with specific induction factors $(28$, $39,51,76,87)$.

Apart from this versatile trans-differentiation potential, ADSCs also exhibit an extensive secretory profile consisting of pro- and anti-inflammatory cytokines, chemokines, and growth factors (73, 77-79, 88-91). Whereas, it was previously thought that ADSCs themselves differentiated to replace injured cells ["host replacement" or "building block" repair theories (30, 80, 81, 92, 93)]; secreted paracrine mediators are now thought to perform key active roles in ameliorating RTX and other injuries (54) by orchestrating autocrine or trophic paracrine effects on surrounding tissues (73). The unique secretory profile of ADSCs indicates that they specifically influence the molecular and biological pathways of tissue regeneration $(67,81-83,94-96)$, angiogenesis $(84,85$, $97,98)$, and lymphangiogenesis $(20,86)$; while suppressing local immune/inflammatory responses $(32,36,75,90,99)$ and reducing fibrogenesis $(39,100)$ (Table 1$)$.

Since their initial description, the cell surface molecular marker profile of ADSCs has remained controversial (51, 131), predominantly due to differences between post-extraction purification protocols, culture conditions, and variations in the use of whole or sub-total SVF $(36,40,62,88-90)$. The International Society for Cellular Therapy defines ADSCs as cells that demonstrate plastic adherence in standard tissue culture conditions $(91,132)$, express a surface marker profile of CD $34^{+}, \mathrm{CD} 31^{-}$, and CD45 ${ }^{-}(2,5,20,21$, 67, 92-95, 98, 133-135) (Figure 2) and demonstrate multi-potent "tri-lineage" differentiation capabilities - i.e., differentiation into bone, cartilage, and fat (101).

\section{ONCOLOGICAL SAFETY OF ADSCs IN RTX-TREATED CANCER BEDS}

Questions regarding oncological safety of fat grafting following cancer clearance have been raised $(36,129,136)$. While longterm tissue changes following fat grafting may impede radiological surveillance for cancer recurrence $(62,137)$, Delay et al. state that experienced breast radiologists should be able to differentiate "post-graft" from malignant calcifications (99). The major oncological concerns relate to the beneficial properties of ADSCs in RTX-injury potentially also promoting tumor growth in areas previously treated for cancer (59, 60, 132-134, 138-140). Molecular adaptations that promote graft survival include secreting hypoxia-induced growth factors such as VEGF-A or VEGF-D (see below) - both of which induce angiogenesis and lymphangiogenesis $(107,108,113,135,141)$ - stimulating breast cancer growth and metastases $(26,59,60,129,130,132-140,142-146)$. Krumboeck et al. found that while ADSCs may not necessarily trigger transformation of quiescent tumor cells to active growth, they could promote proliferation of residual cells after cancer resection and/or adjuvant therapy $(60,147)$. In contrast, proponents of fat grafting argue that in vitro models may not be representative of human tumors $(144,145)$. In light of evidence to date, Claro et al. and Zimmerlan et al. call for postponement of "stem-cell enhanced" fat grafting for breast reconstruction until long-term follow-up data becomes available (42, 44, 60, 132, 145, 
Table 1 | The postulated regenerative mechanisms of ADSCs in clinical and pre-clinical models of tissue injury.

\section{Proposed ADSC regenerative mechanism}

(1) ADSC adipogenic differentiation

\section{Experimental findings supporting regenerative mechanism}

Clinical studies demonstrate newly formed adipose tissue at the site of fat injection resulting in restoration of tissue contour or volume via either $(36,51,99)$

(a) Direct differentiation of injected ADSC to adipocytes (28, 76); or

(b) Paracrine stimulation by injected ADSCs, to influence local stem-cell populations to differentiate into adipocytes $(44,92,101,102)$.

(2) ADSC injection increases perfusion of injured tissues through:

(i) Induction of angiogenesis

(ii) Supporting existing vascular structures

(iii) Paracrine promotion of angiogenesis (a) Fat grafted sites in murine models of ischemic injury demonstrate GFP or Dil-labeled-ADSCs differentiating to CD31+ endothelial cells in vivo $(103,104)$

(b) Increased blood vessel density and co-localization of fluorescently labeled ADSC within/near capillaries $(95,103,105)$

(c) ADSCs form capillary networks on Matrigel matrix and stain positive for VWF $(87,106)$

(d) Release of angiogenic factors by ADSCs promotes re-vascularization and wound healing including: VEGF-A, VEGF-C, VEGF-D, IGF, PDGF-bb, FGF, TGF $\beta$, HGF, IL-6, IL-8, MMP inhibitor

1 precursor, MCP-1, ANG, and SDF-1 (66, 77, 78, 83, 85, 107-110)

\section{(3) ADSCs exert an anti-oxidant effect}

(5) ADSCs modulate granulation tissue, fibrosis, ECM remodeling, and improve epithelialization and
(4) ADSC modulate immune responses, inflammation, and improve wound healing

(a) Anti-oxidant action provides protection against hypoxia, ischemia reperfusion, and ROS induced damage $(81,111,112)$

(b) Factors such as hepatocyte growth factor (HGF), G-CSF, GM-CSF, IGFBPs, IL-12, platelet derived growth factor (PDGF-AA), and Superoxide dismutase may mediate these effects (76)

(a) BMSCs and ADSCs suppress T- and B-cell proliferation via NFkB-mediated mechanisms $(32,66,113)$

(b) Cytokine and adipokine secretion of IL-6 and IL-8 act as chemo-attractants for monocytes and macrophages, with recruitment to site of injury and promotion of wound healing processes $(83,114-116)$

(a) Alteration of collagen type I and III production by fibroblasts co-cultured with ADSC conditioned media, mediated by down-regulation of genes such as Col3a1 (b) Up-regulation of type I procollagen a1 mRNA $(100,117)$

(c) Effective migration of keratinocyte and fibroblasts treated with ADSC conditioned media leading to improved re-epithelialization $(96,117-126)$

(a) Lymphatic fluid stasis results in increased TGF $\beta 1$, exerting a further anti-lymphangiogenic effect. Blockade of TGF $\beta 1$ along with VEGF-C ADSC stimulation resulted in elevated ADSC expression of lymphangiogenic factors; VEGF-C, lymphatic endothelial cell markers; podoplanin and Prox-1 and increased ADSC survival in vitro $(86,127)$

(b) Baseline ADSC production of IL-8, IGF-1, VEGF-D all promote lymphangiogenesis $(77,128)$

(a) Murine models have MSC homing to site of injury. Systemic injected human MSCs migrated and engrafted at the site of ischemic or necrotic injury $(44,48,123-126,129)$

(b) Stromal derived factor $1 \alpha$ (SDF-1 $\alpha$ ) secreted by ADSCs is the main chemo-attractant of systemic stem cells to the area of injury $(112,130)$
148). Gutowski et al. proposed screening to exclude high-risk patients (e.g., with BRACA1/2 mutations) from fat grafting (51, 146). Nevertheless, fat grafting for breast reconstruction has been reported in over 3,000 patients in published studies $(147,149)$. While systematic reviews of current practice examined clinical efficacy, the lack of randomized controlled trials examining oncologic safety and insufficient follow-up of smaller studies mean that no clear conclusions have been reached $(32,54,96,108,145$, 148). Overall, a more detailed understanding of mechanisms by which fat graft may reverse RTX-injury - and how these pathways may cross-talk with the regulation of tumor growth are required.
ADSCS AND RADIOTHERAPY-INDUCED SOFT-TISSUE INJURY Adipose-derived stem cell in the setting of RTX soft-tissue injury raises two broad questions:

(a) The effects of injury on ADSCs.

(b) How ADSCs specifically modulate RTX-Injury.

\section{EFFECTS OF INJURY ON ADSCs Radiotherapy injury, adipocytes, and the SVF}

Injury induced by RTX has previously been explained by rapid, extensive necrotic, or apoptotic cell death in the stem-cell and progenitor populations (23). However, as neither of these 
mechanisms fully account for the chronic, progressive, and evolving nature of RTX-injury in soft-tissues $(10,24)$, "sub-lethal" changes such as premature senescence, terminal differentiation, or reproductive cell death have been implicated $(23,48,150)$. More recent findings suggest that ADSCs display radio-resistance compared with other components of SVF such as adipocytes (150). This may be explained by a greater ability of MSCs to retain their proliferative capacity due to superior DNA damage repair mechanisms compared with those found in terminally differentiated cells (150). Bill et al. suggested that terminal differentiation of cells may correlate with increased G1-cell cycle arrest and reduced ability to repair RTX-induced double-stranded DNA breaks (151). Additionally, reduced metabolic demands of steady-state ADSCs may protect them from hypoxia and subsequent apoptosis, enabling their preservation in order to perform regenerative functions $(39,152)$.

As ADSCs share many regenerative properties with BMSCs, much of our understanding of mechanisms by which healthy ADSCs modulate RTX-injury has been extrapolated from BMSC studies $(54,153)$. Ponomaryov et al. demonstrated that sub-lethal RTX-injury to BMSCs resulted in an increased expression levels of SDF-1 (also the main chemotactic factor for ADSCs) at both mRNA and protein level (130). This increased SDF-1 expression in-turn mediated homing of CXCR4 ${ }^{+}$uninjured stem cells via a chemokine gradient (130). This gradient is integral to homing and importing uninjured ADSCs, as surviving ADSCs originating within the injured area may be significantly functionally impaired $(32,77,86,96,106,108,114,118,119,127,154)$. Poglio et al. characterized the effects of RTX on murine adipose tissue primarily as decreasing adipocyte size and number, increasing ROS, and impairing SVF proliferation and adipogenic differentiation (25). While the overall composition of the SVF was unaltered by irradiation, the authors concluded that changes to the capacity of cells within the SVF to proliferate or differentiate could impair the regenerative properties of fat graft (25), as demonstrated by $\mathrm{Li}$ et al. in irradiated BMSCs, which displayed suppressed proliferation, osteogenesis, and adipogenesis (155). A further mechanism of action of ADSCs maybe a similar recruitment of and differentiation toward a fibroblastic phenotype seen in irradiated BMSCs $(32,156)$.

Functional cellular analysis performed by Schonmyer et al. suggested that irradiated murine BMSCs underwent low-level spontaneous osteoblastic differentiation, in preference to adipogenic or chondrogenic lineages (156). Furthermore, attenuation of the response of irradiated BMSCs to stimulation with lineagespecific differentiation media was decreased in irradiated cells and was associated with down-regulation of bone-specific markers (ALP and osteocalcin) and adipose-specific markers (lipoprotein lipase, $\mathrm{C} / \mathrm{EBPb}$, and leptin) (156). These findings further highlight the altered capacity of stem cells to respond to cues in their microenvironment to replenish damaged cells, following RTX (156). Mechanistically, alterations to paracrine signaling via Wnt10b and Sirtuin-1 (a subset of a family of proteins that regulate stem-cell differentiation) were also seen to mediate altered adipogenesis and osteogenic differentiation characteristics in BMSC (157). Meanwhile, another subset of the same protein family, Wnt3a and Wnt5a, were found to be up-regulated in
RTX-injury and may additionally induce senescence in irradiated BMSCs (30).

\section{HOW ADSCS SPECIFICALLY MODULATE RTX-INJURY?}

The original "building block" theory that stem cells migrate to an area of injury to differentiate and replace the injured cell has been superseded, as only a small number of grafted cells - of which ADSCs make up an even smaller proportion $(44,154)$ - survive the fat transplant injection $(42,77)$. More recently, paracrine mechanisms such as immune-modulation and the generation of protein growth factors secreted by surviving grafted ADSCs, have gained favor $(51,54,102,106,114,149,158)$. Walter et al. demonstrated modulation of keratinocyte and fibroblast migration in response to BMSC conditioned media, in which analysis of the paracrine secretory profile detected increased expression of IL-6, IL-8, MCP1 , and to a lesser degree RANTES and TGF $\beta 1$ proteins $(76,119)$. The key differences in the protein growth factor profiles of the two types of MSCs as shown on cytokine array studies were IL-8, IGF1, and VEGF-D, which were secreted by ADSCs but not BMSCs (77). Given that the mechanisms underlying the overall profile of RTX-injury appear to involve poor vascularity, hypoxia, and lymphedema - and that these three growth factors are implicated in each - it seems intuitive that ADSCs play a critical role in reversing these micro-environmental changes. This protein secretion profile indicates that ADSCs may facilitate angiogenesis and lymphangiogenesis, in addition to the simple anti-fibrotic effects with which they have been previously associated with (36, 100, 113, 141). However, further detailed systematic analysis of the secretory expression profiles of ADSCs is required to identify which specific growth factors are released, under which conditions, and how they may modulate the wound healing, angiogenesis, and lymphangiogenesis $(81,103)$. Such an effect was typified by the down-regulation in VEGF-A production by ADSCs in response to irradiation, as shown by Ebrahimian et al. (87).

\section{ADSCS AND ANGIOGENESIS IN HYPOXIA}

Radiotherapy, particularly associated with subsequent surgery, creates tissue hypoxia by up-regulating expression of inducible transcription factor HIF- $1 \alpha$, either through generating ROS, Nitric Oxide, or inducing macrophage recruitment or release of stress granules (159). In vitro, the constituent components of adipose tissue each responded differently to hypoxic stress stimuli in a study by Haubner et al. (44). These authors found that adipocytes, and to a lesser degree, endothelial cells, underwent apoptosis in hypoxic conditions, while ADSCs displayed superior cell viability (44); a finding verified by Frazier et al. in a viability study (160). Other authors further suggested that the superior survival capacity of ADSCs facilitates their contribution to active repair of adipose tissue $(44,48,85,161)$, and that stem cells are maintained in a baseline state of relative hypoxia, enabling them to derive protection from cyto- or genotoxic stressor by utilizing anaerobic metabolism $(106,159)$. Alternative hypoxic pre-conditioning models such as mechanical thermal stress or nutrient deprivation have also shown superior stem cells survival, in addition to a modified paracrine secretory profile $(35,81,84,85,106,107,154,160,161)$. Unsurprisingly, much of this hypoxia-induced growth factor expression profile is pro-angiogenic. Examples include HIF- $1 \alpha$ and 
SDF-1a production $(84,160)$, which in turn increased secretion of pro-angiogenic and anti-apoptotic cytokines VEGF-A, hepatocyte growth factor (HGF), bFGF, by up to fivefold in spheroid models $(26,81,107,111,161,162)$. Frazier et al. found that ADSCconditioned media (ADSC-CM) from cells grown in hypoxic conditions demonstrated altered protein levels of Fibronectin 1, TGF $\beta 1$-induced protein, Osteonectin, and Collagens (Type 1a1 and 1a2), potentially also facilitating angiogenic sprouts through the ECM $(111,160)$. Despite this compelling pre-clinical work, increased proliferation, migration, or sprouting may not necessarily correlate with the formation of functional vasculature or enhanced tissue perfusion in vivo, without the vessels first acquiring adequate vessel stability $(109,162)$. A study investigating the role of ADSCs in stabilizing endothelial networks attributed them with properties akin to those of pericytes, which act synergistically with blood endothelial cells (BECs) to contribute to neo-angiogenesis. These ADSCs were specifically shown to establish neo-vessel connections with the pre-existing local vasculature and conducted blood flow as a stable network (163). In addition, hypoxia and ischemia have been independently observed to induce trans-differentiation of ADSCs into $\mathrm{CD} 31^{+} / \mathrm{VWF}^{+} \mathrm{BECs}$ that may also contribute to the establishment of neo-vasculature $(96,103,104,109)$. Overall, ADSCs may contribute to angiogenesis by promoting paracrine effects that stabilize neo-vasculature, by supporting existing RTX-damaged blood vessels, or finally, by differentiation into BECs that integrate into forming vessels (103, 164). Local or systemic injection of labeled-ADSCs following body wall RTX treatment were associated with increased angiogenesis consisting of perivascular aggregation of $\mathrm{CD} 31^{+}$ADSCs, which was interpreted as trans-differentiation of ADSCs to BECs (87, $112,164)$.

In addition to pro-angiogenic effects, ADSCs were also shown to display protective effects on non-vascular cells in hypoxic conditions. Lee et al. demonstrated anti-apoptotic effects in dermal fibroblasts, which developed enhanced resistance to oxidative stress when treated with ADSC-CM (76, 111). Similarly, anti-oxidants superoxide dismutase and glutathione activity was enhanced in cell cycle analyses of fibroblasts cultured in ADSCCM (111). In a pre-clinical model of ischemia reperfusion injury, Uysal et al. injected ADSCs into axial flaps, subsequently clamping then finally unclamping the vascular pedicle to allow reperfusion. They showed enhanced flap viability and up-regulated expression of VEGF-A, TGF $\beta$, and FGF proteins detected immunohistochemically (109). Collectively, these findings suggest that ADSCs produce growth factors that may ameliorate ischemic insults and can exert a protective effect against reperfusion injury $(76,109)$.

\section{MECHANISMS OF ADSC-MEDIATED REVERSAL OF RADIOTHERAPY-INDUCED SOFT-TISSUE INJURY}

In addition to anti-hypoxic effects ADSCs have also been shown to mediate alternative paracrine responses to RTX-injury including anti-inflammatory and anti-apoptotic effects (Figure 3).

In an investigation of the effects of irradiation on BECs, Haubner et al. demonstrated up-regulated expression of inflammatory cytokines IL-6, FGF, ICAM1, and VCAM1. Co-culture with ADSCs in this model demonstrated reversed expression of all the detected inflammatory cytokines (66). Similarly, Chang

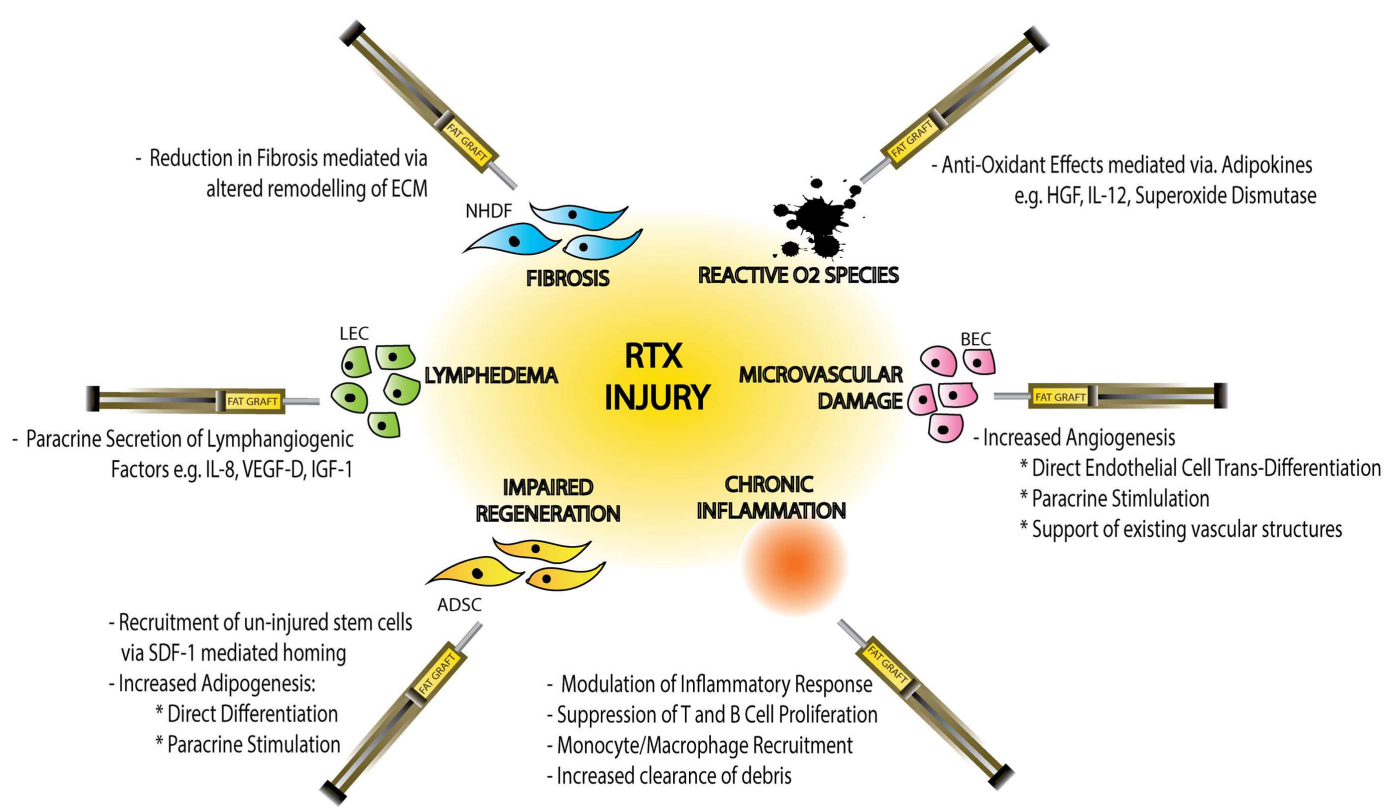

FIGURE 3 | Schematic diagram demonstrating the effects of radiotherapy (RTX)-injury on individual cellular components, the resulting clinical manifestations of injury and the mechanisms by which fat graft may ameliorate this soft-tissue injury. Normal Human Dermal Fibroblasts (NHDF), extracellular matrix (ECM), hepatocyte growth factor (HGF), interleukin-12 (IL-12), blood endothelial cell (BEC), adipose-derived stem cell (ADSC), stromal derived factor-1 (SDF-1), lymphatic endothelial cell (LEC), interleukin-8 (IL-8), vascular derived growth factor-D (VEGF-D), and insulin-like growth factor-1 (IGF-1) 
et al. used a model of intra-peritoneal ADSC injection following abdominal irradiation to demonstrate a significant reduction in inflammation in ADSC-treated animals, with enhanced intestinal re-epithelialization and improved survival rates. ADSC injection was associated with increased serum levels IL10, VEGF-A, bFGF, and EGF as well as enhanced SDF-1-mediated recruitment of hematopoetic stem cells to the site of injury (112). Also in the upper gastrointestinal tract, Lim et al. and Kojima et al. demonstrated protective and anti-apoptotic effects of ADSC injection in a model of RTX-induced salivary gland injury $(165,166)$.

Finally, the dermal and subcutaneous responses to ADSC injection in animal models of both in chronic RTX-wound healing and intact irradiated skin, manifested as increased dermal thickness quantified by a reductions in fibrotic marker Smad-3 and a collagen-based scar index measurement $(164,167)$. An equivalent large animal model of ADSC-enriched fat graft injections following localized RTX demonstrated integration of q-dot-labeledADSCs into the dermis, with associated favorable wound healing, enhanced epithelialization, increased subcutaneous adipose tissue, and reduced apoptosis; along with recruitment and activation of lymphoid cells $(83,168)$.

\section{FUTURE DIRECTIONS AND CONCLUSION}

Significant improvements in cancer therapy have lead to improved cancer survival, meaning that more patients are living longer with the after-effects of RTX. The resulting fibrosis, lymphedema, and impaired tissue quality characteristically reduce the patient's quality of life and complicate subsequent surgery. Recently, fat grafting has been added to plastic surgeons' armamentarium to combat RTX-induced soft-tissue injury. Studies demonstrate the multifaceted nature of ADSC-driven tissue regeneration via enhanced angiogenesis and adipogenesis, while also mediating anti-apoptotic, anti-fibrotic, anti-oxidant, and immunemodulatory properties.

Authors who investigated the effects of injurious stimuli such as hypoxia and radiotherapy on ADSCs have demonstrated a superior ADSC survival capacity compared to other cellular components of fat grafts, through utilization of anaerobic metabolism. However, the sub-lethal RTX-induced injuries impair ADSC proliferative capacity, responsiveness to environmental differentiation cues and alter the ADSC paracrine secretory profile. Such functional alterations in injured ADSCs may account for the inability of local ADSCs to replenish surrounding tissue following radiotherapy injury, thus necessitating the introduction of un-irradiated fat (and ADSCs) in the form of a fat graft. These functional ADSCs may reverse radiation injury by restoring the normal proliferative and differentiation capacity of the local ADSC population.

In conclusion, while in vitro and in vivo models demonstrate the benefits of fat grafting, more comprehensive cellular and molecular analyses using genome-screening platforms are needed to elucidate the true mechanism behind ADSC-mediated reversal of RTX-injury. A detailed understanding of the reaction of individual cell types in response to RTX-injury is required in order to treat pathological processes such as fibrosis, lymphedema, and hypoxia - which contribute to the formation of RTX-induced soft-tissue injury. ADSCs may possess these characteristics; however, a targeted molecular therapy that harnesses the beneficial effects of ADSCs, without raising the potential of enhanced tumor growth, activation, or metastases is required.

\section{ACKNOWLEDGMENTS}

The O'Brien Institute acknowledges funding support from the Victorian State Government's Department of Innovation, Industry and Regional Development's Operational Infrastructure Support Program, Royal Australasian College of Surgeons Foundation for Surgery and Tour de Cure Scholarship, Stafford Fox Medical Research Foundation, Australasian Foundation for Plastic Surgery, LEW Carty Charitable Fund, Joe White Bequest and the Viertel Charitable Foundation.

\section{REFERENCES}

1. Hopewell JW. The skin: its structure and response to ionizing radiation. Int J Radiat Biol (1990) 57(4):751-73. doi:10.1080/09553009014550911

2. Australian Institute of Health and Welfare \& Australasian Association of Cancer Registries 2012. Cancer in Australia: an overview, 2012. Cancer series no. 74. Cat. no. CAN 70. Canberra: AIHW (2012). p. 1-215.

3. Ehrhart EJ, Segarini P, Tsang ML, Carroll AG, Barcellos-Hoff MH. Latent transforming growth factor betal activation in situ: quantitative and functional evidence after low-dose gamma-irradiation. FASEB J (1997) 11(12):991-1002.

4. Baskar R. Cancer and radiation therapy: current advances and future directions. Int J Med Sci (2012) 9(3):193-9. doi:10.7150/ijms.3635

5. Bentzen SM. Preventing or reducing late side effects of radiation therapy: radiobiology meets molecular pathology. Nat Rev Cancer (2006) 6(9):702-13. doi:10.1038/nrc1950

6. Haubner F, Ohmann E, Pohl F, Strutz JR, Gassner HG. Wound healing after radiation therapy: review of the literature. Radiat Oncol (2012) 7(1):1-1. doi:10.1186/1748-717X-7-162

7. Anscher MS. Targeting the TGF-1 pathway to prevent normal tissue injury after cancer therapy. Oncologist (2010) 15(4):350-9. doi:10.1634/theoncologist. 2009-S101

8. Cancer Council. Improving Radiotherapy - Where to From Here? A Roadmap for the NSW Government. Sydney: Cancer Council of New South Wales (2009). p. 1-28.

9. Stone HB, Coleman CN, Anscher MS, McBride WH. Effects of radiation on normal tissue: consequences and mechanisms. Lancet Oncol (2003) 4(9):529-36. doi:10.1016/S1470-2045(03)01191-4

10. Brush J, Lipnick SL, Phillips T, Sitko J, McDonald JT, McBride WH. Molecular mechanisms of late normal tissue injury. Semin Radiat Oncol (2007) 17(2):121-30. doi:10.1016/j.semradonc.2006.11.008

11. Mohanti BK, Bansal M. Late sequelae of radiotherapy in adults. Support Care Cancer (2005) 13(10):775-80. doi:10.1007/s00520-004-0697-z

12. Tibbs MK. Wound healing following radiation therapy: a review. Radiother Oncol (1997) 42(2):99-106. doi:10.1016/S0167-8140(96)01880-4

13. Dormand E-L, Banwell PE, Goodacre TE. Radiotherapy and wound healing. Int Wound J (2005) 2(2):112-27. doi:10.1111/j.1742-4801.2005.00079.x

14. Lee S, Thiele C. Factors associated with free flap complications after head and neck reconstruction and the molecular basis of fibrotic tissue rearrangement in preirradiated soft tissue. J Oral Maxillofac Surg (2010) 68(9):2169-78. doi:10.1016/j.joms.2009.08.026

15. Coleman CN. Effects of radiation on normal tissue: consequences and mechanisms. Science (2004) 304(5671):693-4. doi:10.1126/science.1095956

16. Randall K. Long-term expression of transforming growth factor TGF betal in mouse skin after localized beta-irradiation. Int J Radiat Biol (1996) 70(3):351-60. doi:10.1080/095530096145085

17. Grose R, Werner S. Wound-healing studies in transgenic and knockout mice. Mol Biotechnol (2004) 28(2):147-66. doi:10.1385/MB:28:2:147

18. IMHE. Institute for Health Metrics and Evaluation. Seattle, WA: IMHE, University of Washington (2014). Available from: http://www.healthdata.org

19. Herle P, Shukla L, Morrison WA, Shayan R. Pre-operative radiation and free flap outcomes for head and neck reconstruction: a systematic review and metaanalysis. ANZ J Surg (2014). doi:10.1111/ans.12888

20. Lin C-S, Xin Z-C, Deng C-H, Ning H, Lin G, Lue TF. Defining adipose tissue-derived stem cells in tissue and in culture. Histol Histopathol (2010) 25(6):807-15. 
21. Stewart FA, Akleyev AV, Hauer-Jensen M, Hendry JH, Kleiman NJ, MacVittie TJ, et al. ICRP publication 118: ICRP statement on tissue reactions and early and late effects of radiation in normal tissues and organs. Ann ICRP (2012) 41(1-2):1-322. doi:10.1016/j.icrp.2012.02.001

22. Rodemann HP, Blaese MA. Responses of normal cells to ionizing radiation. Semin Radiat Oncol (2007) 17(2):81-8. doi:10.1016/j.semradonc.2006.11.005

23. Harfouche G, Martin TM. Response of normal stem cells to ionizing radiation: a balance between homeostasis and genomic stability. Mutat Res (2010) 704(1-3):167-74. doi:10.1016/j.mrrev.2010.01.007

24. Denham JW, Hauer-Jensen M. The radiotherapeutic injury - a complex “wound". Radiother Oncol (2002) 63(2):129-45. doi:10.1016/S0167-8140(02) 00060-9

25. Poglio S, Galvani S, Bour S, André M, Prunet-Marcassus B, Pénicaud L, et al. Adipose tissue sensitivity to radiation exposure. Am J Pathol (2009) 174(1):44-53. doi:10.2353/ajpath.2009.080505

26. Kleibeuker EA, Griffioen AW, Verheul HM, Slotman BJ, Thijssen VL. Combining angiogenesis inhibition and radiotherapy: a double-edged sword. Drug Resist Updat (2012) 15(3):173-82. doi:10.1016/j.drup.2012.04.002

27. Mizuno H, Tobita M, Uysal AC. Concise review: adipose-derived stem cells as a novel tool for future regenerative medicine. Stem Cells (2012) 30(5):804-10. doi:10.1002/stem.1076

28. Zuk PA, Zhu M, Mizuno H, Huang J, Futrell JW, Katz AJ, et al. Multilineage cells from human adipose tissue: implications for cell-based therapies. Tissue Eng (2001) 7(2):211-28. doi:10.1089/107632701300062859

29. Milliat F, François A, Isoir M, Deutsch E, Tamarat R, Tarlet G, et al. Influence of endothelial cells on vascular smooth muscle cells phenotype after irradiation. Am J Pathol (2010) 169(4):1484-95. doi:10.2353/ajpath.2006.060116

30. Ross RJ, Shayan R, Mutimer KL, Ashton MW. Autologous fat grafting: current state of the art and critical review. Ann Plast Surg (2014) 73(3):352-7. doi:10.1097/SAP.0b013e31827aeb51

31. Citrin D, Cotrim AP, Hyodo F, Baum BJ, Krishna MC, Mitchell JB. Radioprotectors and mitigators of radiation-induced normal tissue injury. Oncologist (2010) 15(4):360-71. doi:10.1634/theoncologist.2009-S104

32. Marigo I, Dazzi F. The immunomodulatory properties of mesenchymal stem cells. Semin Immunopathol (2011) 33(6):593-602. doi:10.1007/s00281-0110267-7

33. Crop MJ, Baan CC, Korevaar SS, IJzermans JNM, Pescatori M, Stubbs AP, et al. Inflammatory conditions affect gene expression and function of human adipose tissue-derived mesenchymal stem cells. Clin Exp Immunol (2010) 162(3):474-86. doi:10.1111/j.1365-2249.2010.04256.x

34. Chin MS, Freniere BB, Bonney CF, Lancerotto L, Saleeby JH, Lo Y-C, et al. Skin perfusion and oxygenation changes in radiation fibrosis. Plast Reconstr Surg (2013) 131(4):707-16. doi:10.1097/PRS.0b013e3182818b94

35. Rudolph R, Tripuraneni P, Koziol JA, McKean-Matthews M, Frutos A. Normal transcutaneous oxygen pressure in skin after radiation therapy for cancer. Cancer (1994) 74(11):3063-70. doi:10.1002/1097-0142(19941201)74: $11<3063:: A I D-C N C R 2820741126>3.0 . C O ; 2-C$

36. Rigotti G, Marchi A, Galiè M, Baroni G, Benati D, Krampera M, et al. Clinical treatment of radiotherapy tissue damage by lipoaspirate transplant: a healing process mediated by adipose-derived adult stem cells. Plast Reconstr Surg (2007) 119(5):1409-22. doi:10.1097/01.prs.0000256047.47909.71

37. Debels H, Galea L, Han X-L, Palmer J, van Rooijen N, Morrison W, et al. Macrophages play a key role in angiogenesis and adipogenesis in a mouse tissue engineering model. Tissue Eng Part A (2013) 19(23-24):2615-25. doi:10.1089/ten.TEA.2013.0071

38. Coates PJ, Rundle JK, Lorimore SA, Wright EG. Indirect macrophage responses to ionizing radiation: implications for genotype-dependent bystander signaling. Cancer Res (2008) 68(2):450-6. doi:10.1158/0008-5472.CAN-07-3050

39. Tremolada C, Palmieri G, Ricordi C. Adipocyte transplantation and stem cells: plastic surgery meets regenerative medicine. Cell Transplant (2010) 19(10):1217-23. doi:10.3727/096368910X507187

40. Coleman SR. Structural fat grafts: the ideal filler? Clin Plast Surg (2001) 28(1):111-9.

41. Serra-Renom JM, Muñoz-Olmo JL, Serra-Mestre JM. Fat grafting in postmastectomy breast reconstruction with expanders and prostheses in patients who have received radiotherapy: formation of new subcutaneous tissue. Plast Reconstr Surg (2010) 125(1):12-8. doi:10.1097/PRS.0b013e3181c49458
42. Trojahn Kølle S-F, Oliveri RS, Glovinski PV, Elberg JJ, Fischer-Nielsen A, Drzewiecki KT. Importance of mesenchymal stem cells in autologous fat grafting: a systematic review of existing studies. J Plast Surg Hand Surg (2012) 46(2):59-68. doi:10.3109/2000656X.2012.668326

43. Yoshimura K, Sato K, Aoi N, Kurita M, Hirohi T, Harii K. Cell-assisted lipotransfer for cosmetic breast augmentation: supportive use of adipose-derived stem/stromal cells. Aesthetic Plast Surg (2007) 32(1):48-55. doi:10.1007/ s00266-007-9019-4

44. Haubner F, Eto H, Leyh M, Kato H, Ohmann E, Suga H, et al. The fate of adipocytes after nonvascularized fat grafting: evidence of early death and replacement of adipocytes. Plast Reconstr Surg (2012) 129(5):1081-92. doi:10.1097/PRS.0b013e31824a2b19

45. Tabit CJ, Slack GC, Fan K, Wan DC, Bradley JP. Fat grafting versus adiposederived stem cell therapy: distinguishing indications, techniques, and outcomes. Aesthetic Plast Surg (2011) 36(3):704-13. doi:10.1007/s00266-0119835-4

46. Akita S, Yoshimoto H, Ohtsuru A, Hirano A, Yamashita S. Autologous adiposederived regenerative cells are effective for chronic intractable radiation injuries. Radiat Prot Dosimetry (2012) 151(4):656-60. doi:10.1093/rpd/ncs176

47. Mizuno H, Hyakusoku H. Fat grafting to the breast and adipose-derived stem cells: recent scientific consensus and controversy. Aesthet Surg J (2010) 30(3):381-7. doi:10.1177/1090820X10373063

48. Suga H, Eto H, Aoi N, Kato H, Araki J, Doi K, et al. Adipose tissue remodeling under ischemia: death of adipocytes and activation of stem/progenitor cells. Plast Reconstr Surg (2010) 126(6):1911-23. doi:10.1097/ PRS.0b013e3181f4468b

49. Heimburg DV, Hemmrich K, Zachariah S, Staiger H, Pallua N. Oxygen consumption in undifferentiated versus differentiated adipogenic mesenchymal precursor cells. Respir Physiol Neurobiol (2005) 146(2-3):107-16. doi:10.1016/ j.resp.2004.12.013

50. Gimble JM, Guilak F, Bunnell BA. Clinical and preclinical translation of cellbased therapies using adipose tissue-derived cells. Stem Cell Res Ther (2010) 1(2):19. doi:10.1186/scrt19

51. Mazzola RF, Cantarella G, Torretta S, Sbarbati A, Lazzari L, Pignataro L. Autologous fat injection to face and neck: from soft tissue augmentation to regenerative medicine. Acta Otorhinolaryngol Ital (2011) 31(2):59-69.

52. Thanik VD, Chang CC, Lerman OZ, Allen RJ, Nguyen PD, Saadeh PB, et al. A murine model for studying diffusely injected human fat. Plast Reconstr Surg (2009) 124(1):74-81. doi:10.1097/PRS.0b013e3181a80509

53. Zhu M, Zhou Z, Chen Y, Schreiber R, Ransom JT, Fraser JK, et al. Supplementation of fat grafts with adipose-derived regenerative cells improves longterm graft retention. Ann Plast Surg (2010) 64(2):222-8. doi:10.1097/SAP. 0b013e31819ae05c

54. Phinney DG, Prockop DJ. Concise review: mesenchymal stem/multipotent stromal cells: the state of transdifferentiation and modes of tissue repair-current views. Stem Cells (2007) 25(11):2896-902. doi:10.1634/ stemcells.2007-0637

55. Butala P, Sultan SM, Davidson EH, Crawford JL, Szpalski C, Knobel D, et al. Augmentation of fat graft survival with progenitor cell mobilization. Plast Reconstr Surg (2010) 125(Suppl):12. doi:10.1097/01.prs.0000371742. 62300.62

56. Panettiere P, Accorsi D, Marchetti L. The role of free fat graft in breast reconstruction after radiotherapy. Plast Reconstr Surg (1982) 69:195-208.

57. Sterodimas A, de Faria J, Nicaretta B, Pitanguy I. Tissue engineering with adipose-derived stem cells (ADSCs): current and future applications. Br J Plast Surg (2010) 63(11):1886-92. doi:10.1016/j.bjps.2009.10.028

58. Wang WZ, Fang X-H, Williams SJ, Stephenson LL, Baynosa RC, Wong N, et al. Analysis for apoptosis and necrosis on adipocytes, stromal vascular fraction, and adipose-derived stem cells in human lipoaspirates after liposuction. Plast Reconstr Surg (2013) 131(1):77e-85e. doi:10.1097/PRS.0b013e3182729ff7

59. Martin-Padura I, Gregato G, Marighetti P, Mancuso P, Calleri A, Corsini C, et al. The white adipose tissue used in lipotransfer procedures is a rich reservoir of CD34+ progenitors able to promote cancer progression. Cancer Res (2012) 72(1):325-34. doi:10.1158/0008-5472.CAN-11-1739

60. Krumboeck A, Giovanoli P, Plock JA. Fat grafting and stem cell enhanced fat grafting to the breast under oncological aspects - recommendations for patient selection. Breast (2013) 22(5):1-6. doi:10.1016/j.breast.2013.05.006 
61. Rigotti G, Marchi A, Stringhini P, Baroni G, Galiè M, Molino AM, et al. Determining the oncological risk of autologous lipoaspirate grafting for postmastectomy breast reconstruction. Aesthetic Plast Surg (2010) 34(4):475-80. doi:10.1007/s00266-010-9481-2

62. Yoshimura K, Asano Y. Fat injection to the breasts: cosmetic augmentation, implant replacement, inborn deformity, and reconstruction after mastectomy. In: Hall-Findlay EJ, Evans GRD, editors. Aesthetic and Reconstructive Surgery of the Breast. London: Elsevier Ltd (2010). p. 405-20.

63. Nishimura T, Hashimoto H, Nakanishi I, Furukawa M. Microvascular angiogenesis and apoptosis in the survival of free fat grafts. Laryngoscope (2000) 110(8):1333-8. doi:10.1097/00005537-200008000-00021

64. Matsumoto D, Sato K, Gonda K, Takaki Y, Shigeura T, Sato T, et al. Cellassisted lipotransfer: supportive use of human adipose-derived cells for soft tissue augmentation with lipoinjection. Tissue Eng (2006) 12(12):3375-82. doi:10.1089/ten.2006.12.3375

65. Zhu Y, Liu T, Song K, Fan X, Ma X, Cui Z. Adipose-derived stem cell: a better stem cell than BMSC. Cell Biochem Funct (2008) 26(6):664-75. doi: $10.1002 /$ cbf. 1488

66. Haubner F, Leyh M, Ohmann E, Pohl F, Prantl L, Gassner HG. Effects of external radiation in a co-culture model of endothelial cells and adipose-derived stem cells. Radiat Oncol (2013) 8(1):66. doi:10.1186/1748-717X-8-66

67. Varma MJO, Breuls RGM, Schouten TE, Jurgens WJFM, Bontkes HJ, Schuurhuis GJ, et al. Phenotypical and functional characterization of freshly isolated adipose tissue-derived stem cells. Stem Cells Dev (2007) 16(1):91-104. doi:10.1089/scd.2006.0026

68. Yoshimura K, Suga H, Eto H. Adipose-derived stem/progenitor cells: roles in adipose tissue remodeling and potential use for soft tissue augmentation. Regen Med (2009) 4(2):265-73. doi:10.2217/17460751.4.2.265

69. Piccinno MS, Veronesi E, Loschi P, Pignatti M, Murgia A, Grisendi G, et al. Adipose stromal/stem cells assist fat transplantation reducing necrosis and increasing graft performance. Apoptosis (2013) 18(10):1274-89. doi:10.1007/ s10495-013-0878-7

70. Lu F, Li J, Gao J, Ogawa R, Ou C, Yang B, et al. Improvement of the survival of human autologous fat transplantation by using VEGF-transfected adiposederived stem cells. Plast Reconstr Surg (2009) 124(5):1437-46. doi:10.1097/ PRS.0b013e3181babbb6

71. Shoshani O, Livne E, Armoni M, Shupak A, Berger J, Ramon Y, et al. The effect of interleukin-8 on the viability of injected adipose tissue in nude mice. Plast Reconstr Surg (2005) 115(3):853-9. doi:10.1097/01.PRS.0000153036. 71928.30

72. Kølle S-FT, Fischer-Nielsen A, Mathiasen AB, Elberg JJ, Oliveri RS, Glovinski $\mathrm{PV}$, et al. Enrichment of autologous fat grafts with ex-vivo expanded adipose tissue-derived stem cells for graft survival: a randomised placebo-controlled trial. Lancet (2013) 382(9898):1113-20. doi:10.1016/S0140-6736(13)61410-5

73. Caplan AI, Dennis JE. Mesenchymal stem cells as trophic mediators. J Cell Biochem (2006) 98(5):1076-84. doi:10.1002/jcb.20886

74. Nombela-Arrieta C, Ritz J, Silberstein LE. The elusive nature and function of mesenchymal stem cells. Nat Rev Mol Cell Biol (2011) 12(2):126-31. doi:10.1038/nrm3049

75. Fraser JK, Wulur I, Alfonso Z, Hedrick MH. Fat tissue: an underappreciated source of stem cells for biotechnology. Trends Biotechnol (2006) 24(4):150-4. doi:10.1016/j.tibtech.2006.01.010

76. Mizuno H. Adipose-derived stem cells for tissue repair and regeneration: ten years of research and a literature review. J Nippon Med Sch (2009) 76(2):56-66. doi:10.1272/jnms.76.56

77. Hsiao ST-F, Asgari A, Lokmic Z, Sinclair R, Dusting GJ, Lim SY, et al. Comparative analysis of paracrine factor expression in human adult mesenchymal stem cells derived from bone marrow, adipose, and dermal tissue. Stem Cells Dev (2012) 21(12):2189-203. doi:10.1089/scd.2011.0674

78. Kilroy GE, Foster SJ, Wu X, Ruiz J, Sherwood S, Heifetz A, et al. Cytokine profile of human adipose-derived stem cells: expression of angiogenic, hematopoietic, and pro-inflammatory factors. J Cell Physiol (2007) 212(3):702-9. doi:10.1002/ jcp. 21068

79. Blaber SP, Webster RA, Hill CJ, Breen EJ, Kuah D, Vesey G, et al. Analysis of in vitro secretion profiles from adipose-derived cell populations. J Transl Med (2012) 10(1):1-1. doi:10.1186/1479-5876-10-172

80. Neuhof H, Hirshfeld S. The Transplantation of Tissues. New York, NY: D. Appleton (1923). 1 p.
81. Kim W-S, Park B-S, Sung J-H. The wound-healing and antioxidant effects of adipose-derived stem cells. Expert Opin Biol Ther (2009) 9(7):879-87. doi:10.1517/14712590903039684

82. Collawn SS, Banerjee NS, de la Torre J, Vasconez L, Chow LT. Adipose-derived stromal cells accelerate wound healing in an organotypic raft culture model. Ann Plast Surg (2012) 68(5):501-4. doi:10.1097/SAP.0b013e31823b69fc

83. Forcheron F, Agay D, Scherthan H, Riccobono D, Herodin F, Meineke V, et al. Autologous adipocyte derived stem cells favour healing in a minipig model of cutaneous radiation syndrome. PLoS One (2012) 7(2):e31694. doi:10.1371/journal.pone.0031694

84. Bhang SH, Cho SW, La WG, Lee TJ, Yang HS, Sun AY, et al. Angiogenesis in ischemic tissue produced by spheroid grafting. Biomaterials (2011) 32(11):2734-47. doi:10.1016/j.biomaterials.2010.12.035

85. Yuan Y, Gao J, Liu L, Lu F. Role of adipose-derived stem cells in enhancing angiogenesis early after aspirated fat transplantation: induction or differentiation? Cell Biol Int (2013) 37(6):547-50. doi:10.1002/cbin.10068

86. Yan A, Avraham T, Zampell JC, Haviv YS, Weitman E, Mehrara BJ. Adiposederived stem cells promote lymphangiogenesis in response to VEGF-C stimulation or TGF- $\beta 1$ inhibition. Future Oncol (2011) 7(12):1457-73. doi:10.2217/ fon.11.121

87. Ebrahimian TG, Pouzoulet F, Squiban C, Buard V, Andre M, Cousin B, et al. Cell therapy based on adipose tissue-derived stromal cells promotes physiological and pathological wound healing. Arterioscler Thromb Vasc Biol (2009) 29(4):503-10. doi:10.1161/ATVBAHA.108.178962

88. Locke M, Windsor J, Dunbar P. Human adipose-derived stem cells: isolation, characterization and applications in surgery. ANZ J Surg (2009) 79(4):235-44. doi:10.1111/j.1445-2197.2009.04852.x

89. Strioga M, Viswanathan S, Darinskas A, Slaby O, Michalek J. Same or not the same? Comparison of adipose tissue-derived versus bone marrow-derived mesenchymal stem and stromal cells. Stem Cells Dev (2012) 21(14):2724-52. doi:10.1089/scd.2011.0722

90. Cawthorn WP, Scheller EL, MacDougald OA. Adipose tissue stem cells meet preadipocyte commitment: going back to the future. J Lipid Res (2012) 53(2):227-46. doi:10.1194/jlr.R021089

91. Dominici M, Le Blanc K, Mueller I, Slaper-Cortenbach I, Marini F, Krause D, et al. Minimal criteria for defining multipotent mesenchymal stromal cells. The International Society for Cellular Therapy position statement. Cytotherapy (2006) 8(4):315-7. doi:10.1080/14653240600855905

92. Zuk P. Adipose-derived stem cells in tissue regeneration: a review. ISRN Stem Cells (2013) 2013(5):1-35. doi:10.1155/2013/713959

93. Yoshimura K, Shigeura T, Matsumoto D, Sato T, Takaki Y, Aiba-Kojima E, et al. Characterization of freshly isolated and cultured cells derived from the fatty and fluid portions of liposuction aspirates. J Cell Physiol (2006) 208(1):64-76. doi:10.1002/jcp.20636

94. Gronthos S, Franklin DM, Leddy HA, Robey PG, Storms RW, Gimble JM. Surface protein characterization of human adipose tissue-derived stromal cells. J Cell Physiol (2001) 189(1):54-63. doi:10.1002/jcp.1138

95. Baer PC, Geiger H. Adipose-derived mesenchymal stromal/stem cells: tissue localization, characterization, and heterogeneity. Stem Cells Int (2012) 2012(3):1-11. doi:10.1155/2012/812693

96. Heo SC, Jeon ES, Lee IH, Kim HS, Kim MB, Kim JH. Tumour necrosis factor$\alpha$-activated human adipose tissue-derived mesenchymal stem cells accelerate cutaneous wound healing through paracrine mechanisms. J Invest Dermatol (2011) 131(7):1559-67. doi:10.1038/jid.2011.64

97. Matsuda K, Falkenberg KJ, Woods AA, Choi YS, Morrison WA, Dilley RJ. Adipose-derived stem cells promote angiogenesis and tissue formation for in vivo tissue engineering. Tissue Eng Part A (2013) 19(11-12):1327-35. doi:10.1089/ten.TEA.2012.0391

98. Zimmerlin L, Donnenberg AD, Rubin JP, Basse P, Landreneau RJ, Donnenberg VS. Regenerative therapy and cancer: in vitro and in vivo studies of the interaction between adipose-derived stem cells and breast cancer cells from clinical isolates. Tissue Eng Part A (2011) 17(1-2):93-106. doi:10.1089/ten.TEA.2010.0248

99. Delay E, Garson S, Tousson G, Sinna R. Fat injection to the breast: technique, results, and indications based on 880 procedures over 10 years. Aesthet Surg J (2009) 29(5):360-76. doi:10.1016/j.asj.2009.08.010

100. Ohnishi S, Sumiyoshi H, Kitamura S, Nagaya N. Mesenchymal stem cells attenuate cardiac fibroblast proliferation and collagen synthesis through paracrine actions. FEBS Lett (2007) 581(21):3961-6. doi:10.1016/j.febslet.2007.07.028 
101. Zuk PA, Zhu M, Ashjian P, De Ugarte DA, Huang JI, Mizuno H, et al. Human adipose tissue is a source of multipotent stem cells. Mol Biol Cell (2002) 13:4279-95. doi:10.1091/mbc.E02-02-0105

102. Stillaert F, Findlay M, Palmer J, Idrizi R, Cheang S, Messina A, et al. Host rather than graft origin of matrigel-induced adipose tissue in the murine tissue-engineering chamber. Tissue Eng (2007) 13(9):2291-300. doi:10.1089/ ten.2006.0382

103. Lu F, Varma MJO, Mizuno H, Breuls RGM, Uysal CA, Schouten TE, et al. Improved viability of random pattern skin flaps through the use of adiposederived stem cells. Plast Reconstr Surg (2008) 121(1):50-8. doi:10.1097/01.prs. 0000293876.10700.b8

104. Karathanasis V, Petrakis S, Topouridou K, Koliakou E, Koliakos G, Demiri E. Intradermal injection of GFP-producing adipose stromal cells promotes survival of random-pattern skin flaps in rats. Eur J Plast Surg (2013) 36(5):281-8. doi:10.1007/s00238-013-0810-y

105. Zografou A, Tsigris C, Papadopoulos O, Kavantzas N, Patsouris E, Donta I, et al. Improvement of skin-graft survival after autologous transplantation of adipose-derived stem cells in rats. J Plast Reconstr Aesthet Surg (2011) 64(12):1647-56. doi:10.1016/j.bjps.2011.07.009

106. Eto H, Suga H, Inoue K, Aoi N, Kato H, Araki J, et al. Adipose injur-associated factors mitigate hypoxia in ischemic tissues through activation of adiposederived stem/progenitor/stromal cells and induction of angiogenesis. Am J Pathol (2011) 178(5):2322-32. doi:10.1016/j.ajpath.2011.01.032

107. Rehman J. Secretion of angiogenic and antiapoptotic factors by human adipose stromal cells. Circulation (2004) 109(10):1292-8. doi:10.1161/01.CIR. 0000121425.42966.F1

108. Pallua N, Pulsfort AK, Suschek C, Wolter TP. Content of the growth factors bFGF, IGF-1, VEGF, and PDGF-BB in freshly harvested lipoaspirate after centrifugation and incubation. Plast Reconstr Surg (2009) 123(3):826-33. doi:10.1097/PRS.0b013e318199ef31

109. Uysal AC, Mizuno H, Tobita M, Ogawa R, Hyakusoku H. The effect of adiposederived stem cells on ischemia-reperfusion injury: immunohistochemical and ultrastructural evaluation. Plast Reconstr Surg (2009) 124(3):804-15. doi:10.1097/PRS.0b013e3181b17bb4

110. Kapur SK, Katz AJ. Review of the adipose derived stem cell secretome. Biochimie (2013) 95(12):2222-8. doi:10.1016/j.biochi.2013.06.001

111. Kim W-S, Park B-S, Kim H-K, Park J-S, Kim K-J, Choi J-S, et al. Evidence supporting antioxidant action of adipose-derived stem cells: protection of human dermal fibroblasts from oxidative stress. J Dermatol Sci (2008) 49(2):133-42. doi:10.1016/j.jdermsci.2007.08.004

112. Chang P, Qu Y, Liu Y, Cui S, Zhu D, Wang H, et al. Multi-therapeutic effects of human adipose-derived mesenchymal stem cells on radiation-induced intestinal injury. Nature (2013) 4(6):e685. doi:10.1038/cddis.2013.178

113. Benvenuto F, Ferrari S, Gerdoni E, Gualandi F, Frassoni F, Pistoia V, et al. Human mesenchymal stem cells promote survival of T cells in a quiescent state. Stem Cells (2007) 25(7):1753-60. doi:10.1634/stemcells.2007-0068

114. Lee MJ, Kim J, Kim MY, Bae Y-S, Ryu SH, Lee TG, et al. Proteomic analysis of tumour necrosis factor- $\alpha$-induced secretome of human adipose tissue-derived mesenchymal stem cells. J Proteome Res (2010) 9(4):1754-62. doi:10.1021/ pr900898n

115. Jiang D, Qi Y, Walker NG, Sindrilaru A, Hainzl A, Wlaschek M, et al. The effect of adipose tissue derived MSCs delivered by a chemically defined carrier on full-thickness cutaneous wound healing. Biomaterials (2013) 34(10):2501-15. doi:10.1016/j.biomaterials.2012.12.014

116. Chen L, Tredget EE, Wu PYG, Wu Y. Paracrine factors of mesenchymal stem cells recruit macrophages and endothelial lineage cells and enhance wound healing. PLoS One (2008) 3(4):e1886. doi:10.1371/journal.pone.0001886

117. Lee SH, Jin SY, Song JS, Seo KK, Cho KH. Paracrine effects of adipose-derived stem cells on keratinocytes and dermal fibroblasts. Ann Dermatol (2012) 24(2):136-43. doi:10.5021/ad.2012.24.2.136

118. Rodriguez-Menocal L, Salgado M, Ford D, Van Badiavas E. Stimulation of skin and wound fibroblast migration by mesenchymal stem cells derived from normal donors and chronic wound patients. Stem Cells Transl Med (2012) 1(3):221-9. doi:10.5966/sctm.2011-0029

119. Walter M, Wright KT, Fuller HR, MacNeil S, Johnson WEB. Mesenchymal stem cell-conditioned medium accelerates skin wound healing: an in vitro study of fibroblast and keratinocyte scratch assays. Exp Cell Res (2010) 316(7):1271-81. doi:10.1016/j.yexcr.2010.02.026
120. Nambu M, Ishihara M, Kishimoto S, Yanagibayashi S, Yamamoto N, Azuma R, et al. Stimulatory effect of autologous adipose tissue-derived stromal cells in an atelocollagen matrix on wound healing in diabetic $\mathrm{db} / \mathrm{db}$ mice. J Tissue Eng (2011) 2011:158105. doi:10.4061/2011/158105

121. Goh YY, Pal M, Chong HC, Zhu P, Tan MJ, Punugu L, et al. Angiopoietin-like 4 interacts with integrins $\beta 1$ and $\beta 5$ to modulate keratinocyte migration. Am J Pathol (2010) 177(6):2791-803. doi:10.2353/ajpath.2010.100129

122. Walters A, Hulkower KI, Gehler S. Comparison of Oris Cell Migration Assay to Scratch Assay [Internet]. [cited 2014 Sep 7]. Available from: http://www. platypustech.com/ApNote_Platypus_Oris_Scratch.pdf

123. Greenberger JS, Epperly M. Bone marrow-derived stem cells and radiation response. Semin Radiat Oncol (2009) 19(2):133-9. doi:10.1016/j.semradonc. 2008.11.006

124. Bensidhoum M, Gobin S, Chapel A, Lemaitre G, Bouet S, Waksman G, et al. Potentiel thérapeutique des cellules souches mésenchymateuses humaines dans les lésions cutanées radioinduites. J Soc Biol (2005) 199(4):337-41. doi:10.1051/jbio:2005035

125. François S, Mouiseddine M, Mathieu N, Semont A, Monti P, Dudoignon N, et al. Human mesenchymal stem cells favour healing of the cutaneous radiation syndrome in a xenogenic transplant model. Ann Hematol (2006) 86(1):1-8. doi:10.1007/s00277-006-0166-5

126. Mouiseddine M, Francois S, Semont A, Sache A, Allenet B, Mathieu N, et al. Human mesenchymal stem cells home specifically to radiation-injured tissues in a non-obese diabetes/severe combined immunodeficiency mouse model. $\mathrm{Br}$ J Radiol (2007) 80(Special Issue 1):S49-55. doi:10.1259/bjr/25927054

127. Avraham T, Daluvoy S, Zampell J, Yan A, Haviv YS, Rockson SG, et al. Blockade of transforming growth factor- $\beta 1$ accelerates lymphatic regeneration during wound repair. Am J Pathol (2010) 177(6):3202-14. doi:10.2353/ajpath.2010. 100594

128. Ji RC. Lymphatic endothelial cells, inflammatory lymphangiogenesis, and prospective players. Curr Med Chem (2007) 14(22):2359-68. doi:10.2174/ 092986707781745541

129. Zhang Y, Daquinag AC, Amaya-Manzanares F, Sirin O, Tseng C, Kolonin MG. Stromal progenitor cells from endogenous adipose tissue contribute to pericytes and adipocytes that populate the tumour microenvironment. Cancer Res (2012) 72(20):5198-208. doi:10.1158/0008-5472.CAN-12-0294

130. Ponomaryov T, Peled A, Petit I, Taichman RS, Habler L, Sandbank J, et al. Induction of the chemokine stromal-derived factor-1 following DNA damage improves human stem cell function. J Clin Invest (2000) 106(11):1331-9. doi:10.1172/JCI10329

131. Thorne C, Grabb WC, Beasley RW. Grabb and Smith's Plastic Surgery. Philadelphia, PA: Lippincott Williams \& Wilkins (2007). 1 p.

132. Zimmerlin L, Donnenberg AD, Rubin JP, Basse P, Landreneau R, Zimmerlin L, et al. Regenerative therapy and cancer - in vitro and in vivo studies of the interaction between adipose-derived stem cells and breast cancer cells from clinical isolates. Tissue Eng Part A (2011) 17(1-2):93-106. doi:10.1089/ten.TEA.2010.0248

133. Walter M, Liang S, Ghosh S, Hornsby PJ, Li R. Interleukin 6 secreted from adipose stromal cells promotes migration and invasion of breast cancer cells. Oncogene (2009) 28(30):2745-55. doi:10.1038/onc.2009.130

134. Karnoub AE, Dash AB, Vo AP, Sullivan A, Brooks MW, Bell GW, et al. Mesenchymal stem cells within tumour stroma promote breast cancer metastasis. Nature (2007) 449(7162):557-63. doi:10.1038/nature06188

135. Shayan R. Lymphatic vessels in cancer metastasis: bridging the gaps. Carcinogenesis (2006) 27(9):1729-38. doi:10.1093/carcin/bgl031

136. Manabe Y, Toda S, Miyazaki K, Sugihara H. Mature adipocytes, but not preadipocytes, promote the growth of breast carcinoma cells in collagen gel matrix culture through cancer-stromal cell interactions. J Pathol (2003) 201(2):221-8. doi:10.1002/path.1430

137. Prantl L, Muehlberg F, Navone NM, Song Y-H, Vykoukal J, Logothetis CJ, et al. Adipose tissue-derived stem cells promote prostate tumour growth. Prostate (2010) 70(15):1709-15. doi:10.1002/pros.21206

138. Thiery JP, Acloque H, Huang RYJ, Nieto MA. Epithelial-mesenchymal transitions in development and disease. Cell (2009) 139(5):871-90. doi:10.1016/j. cell.2009.11.007

139. Martin M, Remy J, Daburon F. Abnormal proliferation and aging of cultured fibroblasts from pigs with subcutaneous fibrosis induced by gamma irradiation. J Invest Dermatol (1989) 93(4):497-500. doi:10.1111/1523-1747.ep12284053 
140. Xu Q, Wang L, Li H, Han Q, Li J, Qu X, et al. Mesenchymal stem cells play a potential role in regulating the establishment and maintenance of epithelial-mesenchymal transition in MCF7 human breast cancer cells by paracrine and induced autocrine TGF- $\beta$. Int J Oncol (2012) 41(3):959-68. doi:10.3892/ijo.2012.1541

141. Ji R-C. Lymphatic endothelial cells, lymphangiogenesis, and extracellular matrix. Lymphat Res Biol (2006) 4(2):83-100. doi:10.1089/lrb.2006.4.83

142. Iyengar P, Combs TP, Shah SJ, Gouon-Evans V, Pollard JW, Albanese $\mathrm{C}$, et al. Adipocyte-secreted factors synergistically promote mammary tumourigenesis through induction of anti-apoptotic transcriptional programs and proto-oncogene stabilization. Oncogene (2003) 22(41):6408-23. doi:10. 1038/sj.onc. 1206737

143. Yu JM, Jun ES, Bae YC, Jung JS. Mesenchymal stem cells derived from human adipose tissues favor tumour cell growth in vivo. Stem Cells Dev (2008) 17(3):463-73. doi:10.1089/scd.2007.0181

144. Muehlberg FL, Song Y-H, Krohn A, Pinilla SP, Droll LH, Leng X, et al. Tissueresident stem cells promote breast cancer growth and metastasis. Carcinogenesis (2009) 30(4):589-97. doi:10.1093/carcin/bgp036

145. Claro F Jr, Figueiredo JCA, Zampar AG, Pinto-Neto AM. Applicability and safety of autologous fat for reconstruction of the breast. Br J Surg (2012) 99(6):768-80. doi:10.1002/bjs.8722

146. Gutowski KA; ASPS Fat Graft Task Force. Current applications and safety of autologous fat grafts: a report of the ASPS fat graft task force. Plast Reconstr Surg (2009) 124(1):272-80. doi:10.1097/PRS.0b013e3181a09506

147. Agha RA, Goodacre T, Orgill DP. Use of autologous fat grafting for reconstruction postmastectomy and breast conserving surgery: a systematic review protocol. BMJ Open (2013) 3:e003709. doi:10.1136/bmjopen-2013003709

148. Krastev TK, Jonasse Y, Kon M. Oncological safety of autologous lipoaspirate grafting in breast cancer patients: a systematic review. Ann Surg Oncol (2012) 20(1):111-9. doi:10.1245/s10434-012-2565-2

149. Ong WK, Sugii S. The international journal of biochemistry \& cell biology. Int J Biochem Cell Biol (2013) 45(6):1083-6. doi:10.1016/j.biocel.2013.02.013

150. Chen M-F, Lin C-T, Chen W-C, Yang C-T, Chen C-C, Liao S-K, et al. The sensitivity of human mesenchymal stem cells to ionizing radiation. Int J Radiat Oncol Biol Phys (2006) 66(1):244-53. doi:10.1016/j.ijrobp.2006.03.062

151. Bill CA, Grochan BM, Vrdoljak E, Mendoza EA, Tofilon PJ. Decreased repair of radiation-induced DNA double-strand breaks with cellular differentiation. Radiat Res (1992) 132(2):254-8. doi:10.2307/3578534

152. Suga H, Matsumoto D, Inoue K, Shigeura T, Eto H, Aoi N, et al. Numerical measurement of viable and nonviable adipocytes and other cellular components in aspirated fat tissue. Plast Reconstr Surg (2008) 122(1):103-14. doi:10.1097/PRS.0b013e31817742ed

153. Wu Y, Chen L, Scott PG, Tredget EE. Mesenchymal stem cells enhance wound healing through differentiation and angiogenesis. Stem Cells (2007) 25(10):2648-59. doi:10.1634/stemcells.2007-0226

154. Hsiao ST, Dilley RJ, Dusting GJ, Lim SY. Ischemic preconditioning for cellbased therapy and tissue engineering. Pharmacol Ther (2013) 142(2):141-53. doi:10.1016/j.pharmthera.2013.12.002

155. Li J, Kwong DLW, Chan GC. The effects of various irradiation doses on the growth and differentiation of marrow-derived human mesenchymal stromal cells. Pediatr Transplant (2007) 11(4):379-87. doi:10.1111/j.1399-3046.2006. 00663.x

156. Schönmeyr BH, Wong AK, Soares M, Fernandez J, Clavin N, Mehrara BJ. Ionizing radiation of mesenchymal stem cells results in diminution of the precursor pool and limits potential for multilineage differentiation. Plast Reconstr Surg (2008) 122(1):64-76. doi:10.1097/PRS.0b013e31817743cd
157. Su W, Chen Y, Zeng W, Liu W, Sun H. Involvement of Wnt signaling in the injury of murine mesenchymal stem cells exposed to X-radiation. Int J Radiat Biol (2012) 88(9):635-41. doi:10.3109/09553002.2012.703362

158. Hulkower KI, Herber RL. Cell migration and invasion assays as tools for drug discovery. Pharmaceutics (2011) 3(4):107-24. doi:10.3390/ pharmaceutics3010107

159. Dewhirst MW, Cao Y, Moeller B. Cycling hypoxia and free radicals regulate angiogenesis and radiotherapy response. Nat Rev Cancer (2008) 8(6):425-37. doi:10.1038/nrc2397

160. Frazier TP, Gimble JM, Kheterpal I, Rowan BG. Impact of low oxygen on the secretome of human adipose-derived stromal/stem cell primary cultures. Biochimie (2013) 95(12):2286-96. doi:10.1016/j.biochi.2013.07.011

161. Stubbs SL, Hsiao ST-F, Peshavariya HM, Lim SY, Dusting GJ, Dilley RJ. Hypoxic preconditioning enhances survival of human adipose-derived stem cells and conditions endothelial cells in vitro. Stem Cells Dev (2012) 21(11):1887-96. doi:10.1089/scd.2011.0289

162. Vala IS, Martins LR, Imaizumi N, Nunes RJ, Rino J, Kuonen F, et al. Low doses of ionizing radiation promote tumour growth and metastasis by enhancing angiogenesis. PLoS One (2010) 5(6):e11222. doi:10.1371/journal.pone.0011222

163. Traktuev DO, Prater DN, Merfeld-Clauss S, Sanjeevaiah AR, Saadatzadeh MR, Murphy M, et al. Robust functional vascular network formation in vivo by cooperation of adipose progenitor and endothelial cells. Circ Res (2009) 104(12):1410-20. doi:10.1161/CIRCRESAHA.108.190926

164. Huang S-P, Huang C-H, Shyu J-F, Lee H-S, Chen S-G, Chan JY-H, et al. Promotion of wound healing using adipose-derived stem cells in radiation ulcer of a rat model. J Biomed Sci (2013) 20:51. doi:10.1186/1423-0127-20-51

165. Lim J-Y, Ra JC, Shin IS, Jang YH, An H-Y, Choi J-S, et al. Systemic transplantation of human adipose tissue-derived mesenchymal stem cells for the regeneration of irradiation-induced salivary gland damage. PLoS One (2013) 8(8):e71167. doi:10.1371/journal.pone.0071167

166. Kojima T, Kanemaru S-I, Hirano S, Tateya I, Ohno S, Nakamura T, et al. Regeneration of radiation damaged salivary glands with adipose-derived stromal cells. Laryngoscope (2011) 121(9):1864-9. doi:10.1002/lary.22080

167. Sultan SM, Stern CS, Allen RJ Jr, Thanik VD, Chang CC, Nguyen PD, et al. Human fat grafting alleviates radiation skin damage in a murine model. Plast Reconstr Surg (2011) 128(2):363-72. doi:10.1097/PRS.0b013e31821e6e90

168. Chen Y, Niu Z, Xue Y, Yuan F, Fu Y, Bai N. Improvement in the repair of defects in maxillofacial soft tissue in irradiated minipigs by a mixture of adiposederived stem cells and platelet-rich fibrin. Br J Oral Maxillofac Surg (2014) 52(8):740-5. doi:10.1016/j.bjoms.2014.06.006

Conflict of Interest Statement: The authors declare that the research was conducted in the absence of any commercial or financial relationships that could be construed as a potential conflict of interest.

Received: 21 October 2014; paper pending published: 11 November 2014; accepted: 01 January 2015; published online: 28 January 2015.

Citation: Shukla L, Morrison WA and Shayan R (2015) Adipose-derived stem cells in radiotherapy injury: a new frontier. Front. Surg. 2:1. doi: 10.3389/fsurg.2015.00001

This article was submitted to Reconstructive and Plastic Surgery, a section of the journal Frontiers in Surgery.

Copyright (C) 2015 Shukla, Morrison and Shayan. This is an open-access article distributed under the terms of the Creative Commons Attribution License (CC BY). The use, distribution or reproduction in other forums is permitted, provided the original author(s) or licensor are credited and that the original publication in this journal is cited, in accordance with accepted academic practice. No use, distribution or reproduction is permitted which does not comply with these terms. 